Article - Agriculture, Agribusiness and Biotechnology

\title{
Combining Ability for Resistance to White Mold in a Diallel Cross of Soybean
}

\section{Fernanda Aparecida Castro Pereira ${ }^{1^{*}}$}

https://orcid.org/0000-0002-3356-2726

\section{Natal Antonio Vello ${ }^{1}$}

https://orcid.org/0000-0001-7705-2827

\section{Gabriela Antônia de Freitas Rocha ${ }^{1}$}

https://orcid.org/0000-0002-8532-7808

\section{Marcos Custódio Nekatschalow ${ }^{1}$ \\ https://orcid.org/0000-0003-3130-9804}

${ }^{1}$ University of São Paulo, Department of Genetics, Piracicaba, SP, Brazil

Received: 2017.09.20; Accepted: 2019.06.06

* Correspondence: fernandacpereira01@gmail.com; Tel.: +55 35 99912-8794

\section{HIGHLIGHTS}

- The white mold, caused by Sclerotinia sclerotiorum (Lib.) de Bary, is one of the most important diseases of soybean.

- The study of combining ability estimates indicated that there is variability for fungus resistance due to non-additive genes action.

- We found evidence of resistance to $S$. sclerotiorum in crosses and in the parents involved in a diallel cross.

\begin{abstract}
The white mold, caused by Sclerotinia sclerotiorum (Lib.) de Bary, is one of the most important diseases of soybean. The objective of the present work was to evaluate the soybean reaction to the fungus $S$. sclerotiorum, which causes white mold, in a partial diallel with 50 crosses. The Group I of parents was composed of ten experimental lines with high grain yield and the group II consisted in five genotypes with possible resistance to white mold. Ten plants of each cross in the $\mathrm{F}_{4}$ generation and the parents were evaluated for reaction to fungus infection using the method of inoculation in detached leaves in order to assess the severity of the disease and to later estimate the combining abilities. Estimates of the specific combining ability (SCA) was a significant reaction to S. sclerotiorum, indicating that there is variability for fungus resistance due to non-additive genes action.
\end{abstract}

Keywords: Glycine max, Sclerotinia sclerotiorum, breeding, phytopathology. 


\section{INTRODUCTION}

The first white mold epidemic in soybeans fields in Brazil was reported in the 1970s in the state of Paraná [1, 2]. Subsequently, the pathogen was introduced in the Central Region of the country in the early 1980s and, more recently, in the North and Northeast regions. Consequently, it has been the target of research proposals and technology transfer in the current scenario.

The white mold, also called Sclerotinia stem rot is one of the most important diseases of soybean. The causal agent is the fungus Sclerotinia sclerotiorum (Lib.) De Bary [sin. Whetzelinia sclerotiorum (Lib.) Korf \& Dumont]. The incidence of the disease has contributed to the reduction in yield and quality of harvested grains, and it was estimated that this fungus is present in more than six million hectares of soybeans in Brazil [3].

$S$. sclerotiorum is one of the most devastating and important plant pathogens, because it is capable of infecting more than 408 species [4]. One of the most striking features of $S$. sclerotiorum is the formation of sclerotia, a structure of resistance that guarantees the survival of the pathogen in unfavorable environments, which could remain viable for up to 11 years. In addition, this pathogen may also resist as active mycelium in living (especially in seeds) or dead tissues and because of this ability to survive, it becomes highly resistant to chemicals $[5,6]$.

The sclerotia can germinate in two ways, myceliogenic or carpogenic. Myceliogenic germination is characterized by the growth of hyaline, septate, multinucleated and branched hyphae, formed from sclerotium micropores. Carpogenic germination is considered the main cause of epidemics in the field [7]. This germination begins with the growth of fungal cells, called stipes. These in turn, when exposed to the light, differ in apothecias that release thousands of ascospores responsible for initiating the disease in the aerial part of the plant.

In soybean, the infection generally occurs at the junction of the stem and petiole, approximately 10 to $15 \mathrm{~cm}$ above soil level, as well as in inflorescences and lateral branches [8]. The soaked lesions are then rapidly covered by a white mycelium that tends to darken to black, forming the sclerotia that can be produced internally or externally to host tissues. These can be released from the plants naturally or be thrown to the ground by the farmer. When the lesion surrounds the stem, rotting of the lateral stems, pods, leaves and even the main stem is observed, causing death of the plant. It is important to consider that the reduction in grain yield can occur even when the severity of the disease is undetectable in the stems [9].

The period of most vulnerability to infection is from full flowering stage (R2) to the beginning of full seed stage (R5). In conditions of high humidity and temperature around $20^{\circ}$ $\mathrm{C}$, the fungus can colonize healthy tissues between 16 and 24 hours after infection of the floral tissue in senescence. The mycelium can remain viable in infected flowers and it resumes the development when favorable conditions turn back [10].

Currently, no single practice is effective for white mold control. In general, the preventive and integrated management is the alternative in order to recover the grain yield with high pathogen infestation $[11,12]$.

Resistance to $S$. sclerotiorum in soybean has been evaluated in field, greenhouse and laboratory conditions and the responses have ranged from high resistance to full susceptibility [13]. The genetic variability in soybean for resistance to $S$. sclerotiorum has already been reported in the literature [7], but little is known about the variability of Brazilian germoplasm. However, some studies have identified partially resistant genotypes, such as plant introductions (PI, Plant Introduction) $[14,15]$ and resistant Brazilian cultivars: BRSGO Caiapônia [16], EMGOPA313, MSOY6101, EMGOPA316 and BRSGO Milena [17].

The mechanisms of resistance to white mold are associated with physiological (partial) resistance, and mechanisms of escape, including climatic conditions, precocity of flowering and morphological traits related to the architecture of the plant. Similar to beans, the physiological resistance to $S$. sclerotiorum in soybean is polygenically inherited [18].

It is common among researchers the preference to evaluate the disease in the field, but there are some difficulties such as uniformity in infected areas, effective infection of an area 
with sclerotia, besides the dependence of favorable environmental conditions for the disease development. Hence, there are several methods of inoculation in greenhouses and laboratory to evaluate the response of the soybean plant to the stress caused by the fungus [19]. Therefore, the objective of this work was to identify soybean crosses for resistance to white mold and to estimate the combining ability for the reaction to the fungus in a partial diallel scheme.

\section{MATERIAL AND METHODS}

A partial diallel crossing scheme was made between two groups. The group I consisted of ten lines of high grain yield potential, broad adaptability and resistance to the most important diseases and pests, developed by the Department of Genetics, ESALQ-USP, in Piracicaba - SP. Group II was formed by five lines with some degree of resistance with white mold: (BRSGO Caiapônia, EMGOPA313 and MSOY6101), an experimental line (A4725RG) and a plant introduction (PI153.282) (Table 1).

Table 1 - Genealogy of the genotypes used as parents of the partial diallel $10 \times 5$

Groups Genotypes Genealogy

\begin{tabular}{|c|c|c|c|}
\hline \multirow{10}{*}{1} & $1^{*}$ & USP 14-01-20 & Cristalina $\times$ IAC-4 \\
\hline & $2^{*}$ & USP 70.004 & (Soc 81-76 x Foster) $\times$ (IAC Foscarin 31 x Forrest) \\
\hline & $3^{*}$ & USP 70.006 & Foster x FT 79- 3408 \\
\hline & $4^{*}$ & USP 70.010 & (IAC Foscarin $31 \times$ Forrest) $\times($ Foster x FT 79- 3408) \\
\hline & $5^{*}$ & USP 70.042 & (Soc.81-76 x Foster) x Hartwig \\
\hline & $6^{*}$ & USP 70.057 & Kirby $x$ FT-2 \\
\hline & $7^{*}$ & USP 70.080 & (Coker $\times$ Primavera $) \times($ Viçosa $\times$ IAC-10 $)$ \\
\hline & $8^{*}$ & USP 70.108 & Hartwig x PI 371.611 \\
\hline & $9^{*}$ & USP 70.109 & $(\mathrm{IAC}-6 \times$ UFV-4) $\times$ Hartwig \\
\hline & $10^{*}$ & USP 93-05.552 & GO 81-8.491 x BR 80-15.725-B \\
\hline \multirow{5}{*}{2} & $11^{* \star}$ & MSOY 6101 & $\cdots$ \\
\hline & $12^{* *}$ & PI 153.282 & \\
\hline & $13^{\star *}$ & A4725RG & $\cdots$ \\
\hline & $14^{* *}$ & $\begin{array}{l}\text { EMGOPA } 313 \\
\text { BRSGO }\end{array}$ & IAC 7 x (Santa Rosa x G079-3068) \\
\hline & $15^{\star *}$ & Caiapônia & Primavera (OCEPAR 3) x BR 85-6356 \\
\hline
\end{tabular}

* Lines developed for high grain yield and wide adaptability (Sector of Applied Genetics to Autogamous Species, Department of Genetics, ESALQ/USP)

${ }^{* *}$ White mold resistant genotypes.

Crosses were numbered from 101 to 150 (Table 2). 
Table 2 - Design of the $10 \times 5$ partial diallel with 50 crosses between ten parents from Group I and five parents from Group II, with identification numbers varying from 101 to 150 .

\begin{tabular}{llllll}
\hline $\begin{array}{l}\text { Group I x Group II } \\
\mathrm{IN}^{*}\end{array}$ & $\begin{array}{l}(11) \\
\text { MSOY6101 }\end{array}$ & $\begin{array}{l}(12) \\
\text { PI153.282 }\end{array}$ & $\begin{array}{l}(13) \\
\text { A4725RG }\end{array}$ & $\begin{array}{l}(14) \\
\text { EMGOPA313 }\end{array}$ & $\begin{array}{l}\text { BRSGO } \\
\text { Caiapônia }\end{array}$ \\
\hline (1) USP14-01-20 & $1 \times 11_{101}$ & $1 \times 12_{102}$ & $1 \times 13_{103}$ & $1 \times 14_{104}$ & $1 \times 15_{105}$ \\
(2) USP 70.004 & $2 \times 11_{106}$ & $2 \times 12_{107}$ & $2 \times 13_{108}$ & $2 \times 14_{109}$ & $2 \times 15_{110}$ \\
(3) USP 70.006 & $3 \times 11_{111}$ & $3 \times 12_{112}$ & $3 \times 13_{113}$ & $3 \times 14_{114}$ & $3 \times 15_{115}$ \\
(4) USP 70.010 & $4 \times 11_{116}$ & $4 \times 12_{117}$ & $4 \times 13_{118}$ & $4 \times 14_{119}$ & $4 \times 15_{120}$ \\
(5) USP 70.042 & $5 \times 11_{121}$ & $5 \times 12_{122}$ & $5 \times 13_{123}$ & $5 \times 14_{124}$ & $5 \times 15_{125}$ \\
(6) USP 70.057 & $6 \times 11_{126}$ & $6 \times 12_{127}$ & $6 \times 13_{128}$ & $6 \times 14_{129}$ & $6 \times 15_{130}$ \\
(7) USP 70.080 & $7 \times 11_{131}$ & $7 \times 12_{132}$ & $7 \times 13_{133}$ & $7 \times 14_{134}$ & $7 \times 15_{135}$ \\
(8) USP 70.108 & $8 \times 11_{136}$ & $8 \times 12_{137}$ & $8 \times 13_{138}$ & $8 \times 14_{139}$ & $8 \times 15_{140}$ \\
(9) USP 70.109 & $9 \times 11_{141}$ & $9 \times 12_{142}$ & $9 \times 13_{143}$ & $9 \times 14_{144}$ & $9 \times 15_{145}$ \\
(10)USP93-05.552 & $10 \times 11_{146}$ & $10 \times 12_{147}$ & $10 \times 13_{148}$ & $10 \times 14_{149}$ & $10 \times 15_{150}$ \\
\hline
\end{tabular}

* IN: Identification Numbers of the Crosses

The generations were advanced in field trials to the $F_{3}$ generation. The $F_{4}$ seeds were used for the conduction of all the experiments. Five experiments were planted in a completely randomized design to evaluate the fungus reaction. In each experiment there were two replicates, and at each replicate, the 50 crosses were present. In total, each cross was represented by ten $F_{4}$ plants, where one leaf (experimental plot) from each plant was analyzed. In addition, three checks (USP14-01-20, USP70.004 and USP70.108), common to all experiments, were evaluated.

The $\mathrm{F}_{4}$ plants were grown in seedling tubes with commercial substrate inside a shaded place. When the plants reached the $V_{3}$ stage [20], the second trifolium of a plant was collected. Each one was accommodated in a Petri dish, which was previously prepared with two sheets of paper towel and on the top, a glass slide was used to support the detached leaf in order to avoid contact with the wet paper. Thereafter, $10 \mathrm{ml}$ of sterile water was added in each petri dish.

The inoculum was obtained in the city of ljaci, in Minas Gerais State of Brazil, and it was replicated in Petri dishes containing potato dextrose agar (PDA) and then incubated at $20^{\circ} \mathrm{C}$ for about five days in the dark in a Biochemical Oxygen Demand Incubator (BOD Incubator). Mycelial discs with $5 \mathrm{~mm}$ diameter were arranged on the adaxial surface of the detached leaf. The Petri dishes with the inoculated leaves, were maintained at $20^{\circ} \mathrm{C}$ in the dark (BOD).

To measure the infected area, the leaves were photographed at three different times (42, 66 and 90 hours after inoculation), and the images were used to measure the infected area through the program called QUANT v1.0.1 [21]. The R statistical program was used to calculate the area under the disease progress curve (AUDPC) in order to summarize the progress of disease severity [22]. In addition, the resistance of the parents to the fungus was also tested in an experiment conducted in a completely randomized design, with four replicates, and proceeded in the same way as the experiment with the crosses. In order to compare the two groups of parents, a Student's t-test [23] was performed. The test statistics is given by the formula below:

Where:

$$
T=\frac{\mu_{1}-\mu_{2}}{\sqrt{\frac{S_{d 1}^{2}}{n_{1}}+\frac{S_{d 2}^{2}}{n_{2}}}}
$$

$\mu_{1}$ and $\mu_{2}$ represents the mean of each parent group;

$S_{d 1}^{2}$ and $S_{d 2}^{2}$ represents the variance of each parent group;

$n_{1}$ and $n_{2}$ are the number of individuals in each group.

The general combining abilities (GCA) of the parents and the specific combining abilities (SCA) of the crosses for the reaction to $S$. sclerotiorum were estimated according to method 4 
of the Griffing model [24] adapted by [25] for a partial diallel, in order to predict the genetic potential and the performance of the crosses. Using the GENES program [26], the analysis of variance of the diallel was performed using the following mathematical model:

Where:

$$
Y_{i j}=\mu+g_{i}+g_{j}+s_{i j}+e_{i j}
$$

$Y_{i j}$ is the mean of the cross involving the parent $i$ of group I and the parent $j$ of group II; $\mu$ is the general mean of the diallel;

$g_{i}$ is the effect of the general combining ability of the parent $i$ of group I;

$g_{j}$ is the effect of the general combining ability of the parent $j$ of group II;

$s_{i j}$ is the effect of the specific combining ability of the cross between the parents $i$ and $j$

$e_{i j}$ is the mean experimental error.

\section{RESULTS}

The area under the disease progress curve (AUDPC) mean of group I was $100.8 \mathrm{~cm}^{2}$ and group II was $79.84 \mathrm{~cm}^{2}$. The parents with the strongest evidence of resistance were USP $70.080\left(75.03 \mathrm{~cm}^{2}\right)$ of group I and MSOY $6101\left(64.62 \mathrm{~cm}^{2}\right)$ of group II (Table 3).

Table 3 - Parents mean values of reaction to Sclerotinia sclerotiorum (AUDPC, $\mathrm{cm}^{2}$ ), under controlled conditions of temperature and humidity. $F_{4}$ generation.

\begin{tabular}{|c|c|c|c|}
\hline Groups & & Parents & Means $\left(\mathrm{cm}^{2}\right)$ \\
\hline \multirow{10}{*}{ I } & 1 & USP 14-01-20 & 125.09 \\
\hline & 2 & USP 70.004 & 128.79 \\
\hline & 3 & USP 70.006 & 76.592 \\
\hline & 4 & USP 70.010 & 93.35 \\
\hline & 5 & USP 70.042 & 107.04 \\
\hline & 6 & USP 70.057 & 96.99 \\
\hline & 7 & USP 70.080 & 75.03 \\
\hline & 8 & USP 70.108 & 113.86 \\
\hline & 9 & USP 70.109 & 79.45 \\
\hline & 10 & USP 93-05.552 & 112.10 \\
\hline \multirow{5}{*}{ II } & 11 & MSOY 6101 & 64.2 \\
\hline & 12 & PI 153.282 & 110.51 \\
\hline & 13 & A4725RG & 74.66 \\
\hline & 14 & EMGOPA 313 & 79.18 \\
\hline & 15 & Caiapônia & 70.25 \\
\hline
\end{tabular}

Comparing the two groups by the t-test and considering the significance at $5 \%$ level, there was a difference between these two groups, confirming that the parents of the group II had a higher resistance level compared to group $\mathrm{I}$.

The means of AUDPC, in $\mathrm{cm}^{2}$, refer to the severity of the disease of crosses and are presented in Table 4. 
Table 4 - Crosses means values of reaction to Sclerotinia sclerotiorum (AUDPC, $\mathrm{cm}^{2}$ ), under controlled conditions of temperature and humidity. $\mathrm{F}_{4}$ generation.

\begin{tabular}{llllll}
\hline Parents & MSOY 6101 PI 153.282 & A4725RG & EMGOPA 313 & Caiapônia \\
\hline \multirow{2}{*}{ USP 14-01-20 } & 101 & 102 & 103 & 104 & 105 \\
& 283.84 & 207.32 & 243.97 & 233.90 & 268.45 \\
USP 70.004 & 106 & 107 & 108 & 109 & 110 \\
& 236.95 & 264.24 & 237.47 & 223.66 & 235.45 \\
USP 70.006 & 111 & 112 & 113 & 114 & 115 \\
& 156.94 & 237.62 & 189.11 & 286.537 & 270.41 \\
USP 70.010 & 116 & 117 & 118 & 119 & 120 \\
& 237.94 & 239.21 & 281.21 & 239.722 & 247.66 \\
USP 70.042 & 121 & 122 & 123 & 124 & 125 \\
& 250.84 & 227.19 & 227.56 & 238.078 & 252.63 \\
USP 70.057 & 126 & 127 & 128 & 129 & 130 \\
& 199.36 & 241.85 & 246.76 & 222.305 & 235.83 \\
USP 70.080 & 131 & 132 & 133 & 134 & 135 \\
& 161.75 & 264.61 & 171.76 & 255.746 & 287.22 \\
USP 70.108 & 136 & 137 & 138 & 139 & 140 \\
& 233.99 & 246.85 & 246.60 & 253.263 & 257.00 \\
USP 70.109 & 141 & 142 & 143 & 144 & 145 \\
& 258.25 & 140.96 & 252.80 & 248.649 & 162.209 \\
USP 93-05.552 & 146 & 147 & 148 & 149 & 150 \\
& 223.89 & 257.32 & 264.96 & 232.24 & 260.02 \\
\hline
\end{tabular}

The overall mean was $236.88 \mathrm{~cm}^{2}$. This value was higher than that one found for the parents, probably due to the fact that the fungus became more aggressive throughout the successive inoculations. The six crosses more resistant to white mold and that presented the lowest mean AUDPC were 142 (USP 70.109 x PI 152282), 111 (USP 70.006 x M-Soy 6101), 131 (USP 70.080 x M-Soy 6101), 145 (USP 70.109 x BRSGO Caiapônia), 133 (USP $70.080 \times$ A4725 RG) and 113 (USP $70.006 \times$ A4725 RG). The parents USP70.006 $\left(76.59 \mathrm{~cm}^{2}\right)$, USP70.080 $\left(75.03 \mathrm{~cm}^{2}\right)$, USP70.109 $\left(79.45 \mathrm{~cm}^{2}\right)$ and A4725RG $\left(74.66 \mathrm{~cm}^{2}\right)$ are present in two crosses out of the six indicated above and possibly these parents provide white mold resistance alleles. Of the 50 crosses studied, 18 presented averages below the general average of the crosses, which represents greater resistance.

The Table 5 summarizes the information about the diallel analysis involving the 50 crosses and the 15 parents, in which significance was observed for crossings, and for the estimation of specific combining ability (SCA).

Table 5 - Analysis of variance of the parents and the crosses from the partial diallel for reaction to Sclerotinia sclerotiorum (AUDPC, $\mathrm{cm}^{2}$ ), under controlled conditions of temperature and humidity. $\mathrm{F}_{4}$ generation.

\begin{tabular}{lll}
\hline & & Mean squares \\
\cline { 3 - 3 } SV & DF & AUDPC $\left(\mathbf{c m}^{2}\right)$ \\
\hline Crosses & 49 & $10972.5^{* *}$ \\
GCA Group I & 9 & 7265.1 \\
GCA Group II & 4 & 8338.9 \\
SCA Ixll & 36 & $12192.0^{* *}$ \\
Error & 412 & 4686 \\
\hline
\end{tabular}

Notes: ${ }^{* *}$ significant at $1 \%$ probability, for the $\mathrm{F}$ test

Estimates of SCA $\left(s_{i j}\right)$ effects (Table 6 ) are used to identify crosses that behave relatively worse, or better, than what is expected based on GCA $\left(g_{i}\right.$ and $\left.g_{j}\right)$ estimates. 
Table 6 - Estimation of General (GCA) and Specific Combining Ability (SCA) by Griffing method 4, for reaction to Sclerotinia sclerotiorum (AUDPC, $\mathrm{cm}^{2}$ ) in a partial dialel $10 \times 5$.

\begin{tabular}{lllllll}
\hline GI/GII & MSOY6101 & PI153.282 & A4725RG & EMGOPA313 & Caiapônia & $\begin{array}{c}\text { GCA } \\
\left(\mathbf{g}_{\text {iGI }}\right)\end{array}$ \\
\hline USP 14-01-20 & 101 & 102 & 103 & 104 & 105 & 10.61 \\
& 48.84 & -36.01 & -2.86 & -20.12 & 10.14 & \\
USP 70.004 & 106 & 107 & 108 & 109 & 110 & 2.673 \\
& 9.90 & 28.85 & -1.42 & -22.41 & -14.91 & \\
USP 70.006 & 111 & 112 & 113 & 114 & 115 & -8.756 \\
& -58.67 & 13.66 & -38.35 & 51.88 & 31.48 & \\
USP 70.010 & 116 & 117 & 118 & 119 & 120 & 12.26 \\
& 1.30 & -5.77 & 32.72 & -15.95 & -12.29 & \\
USP 70.042 & 121 & 122 & 123 & 124 & 125 & 2.378 \\
& 24.08 & -7.90 & -11.03 & -7.710 & 2.56 & \\
USP 70.057 & 126 & 127 & 128 & 129 & 130 & -7.660 \\
& -17.35 & 16.78 & 18.20 & -13.44 & -4.19 & \\
USP 70.080 & 131 & 132 & 133 & 134 & 135 & -8.666 \\
& -53.96 & 40.55 & -55.79 & 21.001 & 48.19 & \\
USP 70.108 & 136 & 137 & 138 & 139 & 140 & 10.65 \\
& -1.045 & 3.47 & -0.27 & -0.805 & -1.34 & \\
USP 70.109 & 141 & 142 & 143 & 144 & 145 & -24.31 \\
USP & 58.18 & -67.44 & 40.88 & 29.54 & -61.17 & \\
93-05.552 & 146 & 147 & 148 & 149 & 150 & 10.80 \\
\hline GCA (9 & -11.29 & 13.80 & 17.93 & -21.97 & 1.53 & \\
\hline
\end{tabular}

The parents USP70.109, USP70.006, USP70.080 and USP70.057 from group I and MSOY6101 and PI 153282 from group II contributed the most to the generation of $S$. sclerotiorum-resistant offspring, obtaining the lowest $g_{i}$ negative effects. Only the performance of USP70.006 agreed with previous conclusions based on severity means. The highest $g_{i}$ positive effects were found in USP93-05.552 and USP70.010 in group I, as well as in EMGOPA313 and Caiapônia in group II, these parents had little contribution to the formation of combinations with resistance to the pathogen

The crosses with dominance patterns for the resistance were those with negative SCA estimates, represented by 142 (USP70.109 x PI153.282), 145 (USP70.109 x Caiapônia), 111 (USP70.006 x MSOY6101), 133 (USP70.080 x A4725RG) and 131 (USP70.080 $\mathrm{x}$ MSOY6101).

The crosses with the greatest $s_{\mathrm{ij}}$ positive effects were 141 (USP70.109 x MSOY 6101), 114 (USP70.006 x EMGOPA 313), 101 (USP14-01-20 x MSOY6101), 135 (USP70.080 x Caiapônia) and 143 (USP70.109 x A4725RG), showing a pattern of susceptibility to the fungus. Only two crosses presented absolute values close to zero: 138 (USP $70.108 \times$ A4725RG) and 139 (USP 70.108 x EMGOPA 313).

The three checks involved in the five experiments are among the most susceptible parents, T1 (USP 14-01-20) in the first position, T2 (USP 70.004) in the second position and T3 (USP 70,108) in the third position. When compared to crosses, they are among the 16 most susceptible genotypes. These common checks allowed the joint evaluation of all five experiments.

\section{DISCUSSION}

It is common to find studies in which variation in resistance to $S$. sclerotiorum among genotypes is high [14, 19, 27]. Therefore, the pathogen isolates, the inoculation techniques and the statistical analysis must be chosen correctly, since these are determinants for the success in the identification of resistant cultivars [28]. 
The cultivar Caiapônia was moderately resistant, and EMGOPA313 was considered resistant using the same method [17]. There was identified $68 \mathrm{Pls}$ that were partially resistant in field evaluations, and one of them was PI 153.282 [29], used in this work. As this PI has shown to be more resistant, this fact indicates that the detached leaf method has a positive correlation with field evaluations as observed in other studies [13, 15]. This is a non-destructive method, which has the advantage of allowing multiple trials throughout the years, besides presenting a good environmental control.

A diagrammatic scale was developed to assess soybean white mold severity, considering this type of inoculation [17]. However, the estimation of the lesion area guarantees greater precision in the evolution of the disease severity [28, 30].

SCA results from the dominant genetic variance, showing that for the expression of this character, the additive, dominant and probably epistatic genes actions were important. Therefore, there is variability for white mold resistance due to the non-additive action of the genes. The non-additive variance, expressed by the mean squares of SCA, is comparatively higher than the additive variance. Based on this information, the development of base populations from genetically superior parents of the two groups is feasible and it can provide satisfactory gains by the selection of individuals in segregating generations [31]. In a breeding program, knowledge of the type of gene action that prevails on the genetic basis of a trait is an important factor [32].

The crosses that presented absolute values close to zero indicate that the crossing behavior would be in accordance to the expected from the GCA of their parents. On the other hand, when the $s_{\mathrm{ij}}$ estimation of a cross has a high absolute value (positive or negative), it suggests a crossing with performance better or worse than what is expected based on the general combining ability of the parents [33].

As a conclusion, there were small variations in plant resistance levels to white mold, and presented evidence of resistance to $S$. sclerotiorum in crosses and in the parents. The study of combining ability estimates indicated that there is variability for fungus resistance due to non-additive genes action.

\section{REFERENCES}

1 - Henning, A.A. Patologia e tratamento de sementes: noções gerais. Londrina: Embrapa CNPSo: Londrina, PR, Brazil. 2004. 51p.

2 - Yamashita, J.; Nasser, L.C.B.; Almeida, A.M.R.; Machado, C.C.; Ferreira, L.P. (1978) Ocorrência da fase perfeita do fungo Whetzelinia sclerotiorum (Lib.) Korf \& Dumont, em lavouras de soja no Estado do Paraná. Fitopatologia Brasileira 3(1): 109.

3 - Juliatti, F.C.; Juliatti, F.C.A. Podridão branca da haste da soja: Manejo e uso de fungicidas em busca da sustentabilidade nos sistemas de produção. Composer: Uberlândia, MG, Brazil. 2010. 33p.

4 - Adams, P.B.; Ayers, W.A. Ecology of Sclerotinia species. Phytopathology 1979, 69(8), 896-899.

5 - Kimati, Y.; Bergamin-Filho, A. Princípios gerais de controle. In: Amorim L, Rezende JAM and Bergamin Filho A (ed.) Manual de Fitopatologia: princípios e conceitos. 4. ed. São-Paulo: Ceres, 2011, 704p.

6 - Zambolim, L.; Venâncio, S.V.; Oliveira, S.H.F. Manejo da Resistência de Fungos a Fungicidas. Visconde do Rio Branco: Suprema Gráfica e Editora, 2007, 168p.

7 - Gorgen, C.A.; Hikishima, M.; Silveira Neto, A.N.; Carneiro, L.C.; Lobo Junior, M. Mofo branco (Sclerotinia sclerotiorum). In: Almeida AMR and Seixas CDS (ed.) Soja: doenças radiculares e de hastes e inter-relações com o manejo do solo e da cultura. Londrina: Embrapa Soja, 2010, 399p.

8 - Grau, C.R.; Hartman, G.L. Sclerotinia stem rot. In: Hartman GL, Sinclair JB and Rupe JC (ed.) Compedium of soybean diseases. St Paul: APS Press, 1999, p. 46-48.

9 - Yang, X.B.; Lundeen, P.; Uphoff, M.D. Soybean varietal response and yield loss caused by Sclerotinia sclerotiorum. Plant Disease 1999, 83(5), 456-461.

10 - Danielson, G.A.; Nelson, B.D.; Helms, T.C. Effect of Sclerotinia stem rot on yield of soybean inoculated at different growth stages. Plant Disease 2004, 88, 297-300. 
11 - Silva, L.H.C.P.; Campos, H.D.; Silva, J.R.C. Manejo do mofo branco da soja. In: Silva, L. H. C. P.; Campos, H. D.; Silva, J. R. C. (Ed.). Manejo fitossanitário de cultivos agroenergéticos. Lavras: UFLA, 2010. p - 205-214.

12 - EMBRAPA SOJA. Tecnologias de produção de soja - Região Central do Brasil 2014. - Londrina: Embrapa Soja/Sistemas de Produção, 2013, 265p.

13 - Wegulo, S.N.; Yang, X.B.; Martinson, C.A. Soybean cultivar responses to Sclerotinia sclerotiorum in field and controlled environment studies. Plant Disease 1998, 82(11), 1264-1270.

14 - Arahana, V.S.; Graef, G.L.; Specht, J.E.; Steadman, J.R.; Eskridge, K.M. Identification of QTLs for resistance to Sclerotinia sclerotiorum in soybean. Crop Science 2001, 41, 180-188.

15 - Kim, H.S.; Diers, B.W. Inheritance of partial resistance to Sclerotinia stem rot in soybean. Crop Science 2000, 40, 55-61.

16 - Nunes Junior, J.M.; Assunção, M.S.; Faria, L.C.; Guerzoni, R.A.; Silva, J.F.V.; Yorinori, J.T.; Souza, P.I.M.; Arantes, N.E.; Guimarães, L.B.; Silva, L.O.; Neiva, L.C.S.; Vieira, N.E. Cultivar de soja BRSGO Caiapônia: comportamento, descrição e indicação de cultivo para os estados de Goiás, Distrito Federal, Minas Gerais, Mato Grosso e Bahia. In: REUNIAO DE PESQUISA DE SOJA DA REGIAO CENTRAL DO BRASIL, 24., 2002, São Pedro, SP. Resumos... Londrina: Embrapa Soja.

17 - Garcia, R.A.; Juliatti, F.C. Avaliação da resistência da soja a Sclerotinia sclerotiorum em diferentes estádios fenológicos e períodos de exposição ao inóculo. Tropical Plant Pathology 2012, 37 (3), 196-203.

18 - Fuller, P.A.; Coyne, D.P.; Steadman, J.R. Inheritance of resistance to white mold disease in a diallel cross of dry beans. Crop Science 1984, 24: 929-933.

19 - Botha, C.; Mclaren, N.; Swart, W. Evaluation of greenhouse inoculation techniques used to screen for Sclerotinia stem rot resistance in soybeans. South African Journal of Plant and Soil, 2009, 26(1), 48-50.

20 - Fehr, W.R.; Caviness, C.E. Stages of soybean development. Ames: lowa State University. 1977. $12 p$.

21 - Vale, F.X.R.; Fernandes Filho, E.R.; Liberato, J.R. QUANT - a software for plant disease severity assessment. International Congress of Plant Pathology. Anais...Christchurch, New Zeland. 2003.

22 - Shaner, G.; Finney, R.E. The effect of nitrogen fertilization on the expression of slow-mildewing resistance in Knox wheat. Phytopathology 1977, 67, 1051-1056.

23 - Student. The probable error of a mean. Biometrika, 6: 1-25.

24 - Griffing, B. Concept of general and specific combining ability in relation to diallel crossing systems. Australian Journal Biology Science 1956, 9, 463-493.

25 - Geraldi, I.O.; Miranda Filho, J.B. Adapted models for the analysis of combining ability of varieties in partial diallel crosses. Revista Brasileira de Genética, 1988, 11, 419-430.

26 - Cruz, C.D. GENES - a software package for analysis in experimental statistics and quantitative genetics. Acta Scientiarum. 2013, 35(3), 271-276.

27 - Cunha, W.; Tinoco, M.L.P.; Pancoti, H.L.; Ribeiro, R.E.; Aragão, F.J.L. High resistance to Sclerotinia sclerotiorum in transgenic soybean plants transformed to express an oxalate decarboxylase gene. Plant Pathology, v. 59, n. 4, p. 654-660, 2010.

28 - Kull, L.S.; Vuong, T.D.; Eskridge, K.M.; Steadman, J.R.; Hart, G.L. Evaluation of resistance screening methods for Sclerotinia stem rot of soybean and dry bean. Plant Disease 2003, 87(12), 1471-1476.

29 - Hoffman, D.D.; Diers, B.W.; Hartman, G.L.; Nickell, C.D.; Graef, G.L.; Steadman, J.R.; Grau, C.R.; Nelson, B.D.; Del Rio, L.E.; Helms, T.C.; Anderson, T.; Poysa, V.; Rajcan, I.; Stienstra, W.C. Selected soybean Plant Introductions with partial resistance to Sclerotinia sclerotiorum. Plant Disease, 2002, 86 (9), 971-980.

30 - Kim, H.S.; Hartman, G.L.; Manandhar, J.B.; Graef, G.L.; Steadman, J.R.; Diers, B.W. Reaction of soybean cultivars to Sclerotinia Stem Rot in field, greenhouse, and laboratory evaluations. Crop Science, 2000, 40, 665-669.

31 - Ramalho, M.A.P.; Abreu, A.F.B.; Santos, J.B.; Nunes, J.A.R. Aplicações da genética quantitativa no melhoramento de plantas autógamas. Lavras: Editora UFLA, 2012. 522p. 
32 - Bernardo, R. Breeding for quantitative traits in plants. 2nd ed. Woodbury: Stemma Press. 2010. $369 \mathrm{p}$.

33 - Vencovsky, R.; Barriga, P. Genética biométrica no fitomelhoramento. Ribeirão Preto: Sociedade Brasileira de Genética, 1992, 496p.

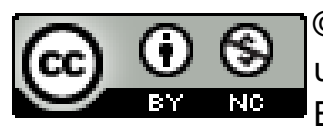

(c) 2018 by the authors. Submitted for possible open access publication under the terms and conditions of the Creative Commons Attribution (CC BY NC) license (http://creativecommons.org/licenses/by-nc/4.0/). 